\title{
THE ENVIRONMENT AS PROMISE AND PROBLEM IN THE OLD TESTAMENT
}

\author{
Douglas Lawrie \\ Department of Religion and Theology \\ University of the Western Cape
}

\begin{abstract}
The article argues that discourse about the Bible and the environment is often insufficiently materialistic and insufficiently theological. Ideas are not the motive force of history, but arise in a complex dialectic in which humans create and are created by their environment (Marx). This is briefly illustrated by examples from the Old Testament, focusing on how Israel encountered her environment as promise and problem. When it comes to disinterested concern for the earth, however, we have to go beyond this - closer to God, not closer to nature which offers no unambiguous moral resources. This too is implicit in the Bible.
\end{abstract}

Keywords: Ecology, Palestinian Geography, Creation, Human Mastery, Materialism

\section{Lessons from a Materialist}

In The German Ideology, Karl Marx attacks Hegelians for rehearsing world history "in the realm of pure thought" (1970:39). Whereas they start from and remain within the sphere of "conceptions, thoughts, ideas, in fact all the products of consciousness" (41), Marx's premise is "real individuals, their activity and the material conditions under which they live" (42). "Men must be in a position to live in order to be able to "make history", for "life involves before anything else eating and drinking, a habitation, clothing and many other things" (48). People's interaction with nature and other people determines their thoughts, concerns and interests. "Life is not determined by consciousness, but consciousness by life" (47). Though Marx qualifies this elsewhere, ${ }^{1}$ two aspects of Marx's materialism help us when we seek guidance from ancient texts about humans and the environment.

First, although in the world of pure concepts 'humans' and 'the environment' appear as timeless relata, our conceptions of what 'humans' and 'the environment' are change. ${ }^{2}$ To judge conceptions that prevailed in the past without placing them in historical context is risky; to establish what belongs to an age in its historical specificity and what to the generalities of human history that we share across centuries implies a God's eye view. This is the truth in Ranke's dictum: 'Each age is immediate to God'. Secondly, if the products of consciousness are not fully and predictably determined by material life, such products also do not determine how people actually live. Any view of how humans do or should relate to their environment is preceded and influenced by a specific 'mode of life' (Marx 1970:42), a set of largely unreflected interactive practices. Though our practices and our reflection on

\footnotetext{
Marx explicitly rejects environmental determinism in his third thesis on Feuerbach (1978a:144) and often clearly states his dialectical position (e.g. 1978b:595). For a balanced discussion, see Avineri 1971:65-76.

2 Thus Marx (1970:51) argues that the earliest humans had 'a purely animal consciousness of nature', which "first appears to men as a completely alien, all-powerful and unassailable force ... by which they are overawed like beasts".
} 
them tend to influence each other, they are not seamlessly joined. ${ }^{3}$ Not only do the conditions of life often appear in inverted form in human ideologies (Marx 1970:47), but both reprehensible and laudable human ideas are imperfectly implemented because real or perceived constraints from the 'living world' get in the way.

The cradle of the Old Testament, the Ancient Near East, had its specific mode of life in which the material conditions of life, without wholly determining thought, facilitated some lines of thinking and obstructed others. Here people had produced a civilization, a social order based on sizeable permanent settlements sustained by intensive cultivation. Surplus food production freed many people from the battle for survival, allowing them to develop an increasingly humanized environment, but the non-human environment continued to present both promises and problems. It offered useful plant and animal species with one hand and arid areas, marshes, rocky hills and mountains with the other. The hubs of this world, Egypt and Mesopotamia, lacked forests to supply wood for construction work. Large or venomous wild animals still, on the whole, posed a greater threat to humans than humans did to them. That 'wild nature' ${ }^{4}$ could swallow civilization, at least in some areas, seemed a real possibility. ${ }^{5}$ If we forget this, we may 'colonize' ideas from this world without noticing that they played a completely different role in their original setting and cannot bear the 'messages' we now foist on them.

\section{Locating Human Interests and Concerns}

Biblical Hebrew lacked a word corresponding to the Greek pvoıs or the Latin natura: in medieval times, rabbinical scholars created a word (from an existing Hebrew root) to fill the gap (Jacob 1995:364). Perhaps Israelites thought in terms of 'creation' rather than 'nature' (Tucker 1997:17), yet this is hard to prove. Though nouns from ברא 'צר exist, they are not used of 'the cosmos as creation'. 6 Though ancient people often lacked a specific word for nature (or for the cosmos as a natural whole), the presence or absence of a term says little about the conceptions people entertain. In the Tao Te Ching, for instance, what we call 'nature' appears both as a unity, the Way (Tao) or natural order, and, in its concrete multiplicity, as 'the myriad of things'. How, then, can we study people's interests in and concerns for nature ? $^{7}$ Instead of analysing their concepts, we may follow Marx and imagine their concrete lives (cf. Hillel 2006:7).

3 Marx's view is confirmed in ironic fashion in his writings. Being a city man at the time of the industrial revolution, Marx has little interest in agricultural production. He praised capitalism for rescuing many 'from the idiocy of rural life' (Marx \& Engels 1948:13), momentarily forgetting that the industrial proletariat developed a class consciousness on food produced by rural idiots. Elsewhere he speaks of the 'civilizing influence of capital', which led to the 'universal appropriation of nature' and banished 'nature-idolatry' by 'helping to subjugate [nature] to human needs' (1973:409f). Today he might have written differently.

4 Boersema (1997:208) rightly draws attention to the distinction between domesticised and 'wild' nature which is implicit in the Old Testament.

5 Levenson (1994:passim) deals admirably with this constant threat of 'chaos'. After careful study, Watson (2005:397) concludes that the term 'chaos' and notions of the Chaoskampf should be abandoned, but she cannot deny that the fear of incursions of the chaotic (in many forms) permeates the Old Testament.

6 Examining the Hebrew terminology does not get us much further. ארץ is used indeterminately for the world, a country, a region or land in general; אדמה often, not invariably, refers specifically to arable land. The poetic תבל may refer to the world as productive (thus coming closer to natura) or to the world as 'procession of events'.

7 I sometimes use 'nature' for the cumbersome 'non-human nature' even though humans are obviously part of nature. No terminology is without problems: the distinction between nature and culture remains useful. 
From her flat in a modern European city, Ms X commutes to the office where she is a junior in an accounting firm. Between doing her own housekeeping, climbing the corporate ladder and socializing, her environment on weekdays is, physically and mentally, predominantly a product of human activity. Tar and cement fill her eyes, city noise and music her ears, petrol fumes, deodorants and disinfectants her nose, balance sheets and human relationships her mind. On an average day, a few street trees, some potted plants and a sliver of sky above the skyscrapers are all she sees of non-human nature - if she even notices these things. Yet she has an interest in and concern for non-human nature. Being an ardent and expert bird watcher, she often spends weekends in parks or forests with her binoculars. She loves nature programmes on television and dreams of visiting centres of biodiversity. Because she is concerned about global warming, she tries to reduce her carbon footprint. Still, she uses air conditioning to keep her apartment and office at a constant temperature throughout the year. And though she knows that a paper mill pumps toxic waste into a wetland that houses many bird species, she does not mention it at work. The mill owner is a valued client of the firm and she a replaceable underling. Indeed, she seldom speaks of her concern for the environment, for other concerns usually take precedence.

Mr Y, a Palestinian peasant living 2700 years ago, has to pay taxes and feed a wife and four children, all too young to be useful, from a plot of land and handful of sheep and goats. Most of his waking hours are spent with non-human nature as his sole companion. Often he is glad to get indoors, out of the blazing sun or driving rain and into human company. Outside he has to wrestle with elements over which he ultimately has no effective control. He can protect his flock against predators - sometimes. When droughts or unseasonable rains strike, no amount of hard work or farming skill saves the harvest. To survive, he has to know his environment and live in harmony with it. He is interested in animals in that they represent promises - as food - or potential problems - as predators. $\mathrm{He}$ is a conservationist in that he has terraced the slopes to protect his fields against erosion. If a lamb gets caught in a late frost, he warms it against his breast. He uses the natural resources of his world, firewood, for instance, sparingly: they are limited and cannot be replaced. In bad years, however, he cannot prevent overgrazing. He is sometimes interested in nature as more than a means to his ends. He notices the beauty of sunsets and spring flowers. He has placed a fallen fledgling back in the nest. Some of his sheep are his friends and, yes, he does speak to them. That lions, apart from being dangerous, are also majestic has not passed him by. In a way he loves the very ground under his feet, every pebble and every shrub, because it is his inheritance, his home, the place without which he would not be what he is. His life, though centred on nature, is not the less anthropocentric for that.

Though Ms X and Mr Y are figments of my imagination, I submit that they are closer to the lived reality we know than variously configured constellations of abstract ideas. ${ }^{8} \mathrm{Mr} \mathrm{Y}$ is more intimately concerned with nature than $\mathrm{Ms} \mathrm{X}$ is; he is not necessarily more deeply concerned about the environment than she is. She, thanks to her education, understands natural processes better than he does; he, however, experiences them more intensely. His interest in nature is in most ways more extensive than hers; hers is in some ways more disinterested than his. In some ways both are 'immediate to God'. Those who, in the interest of the biosphere, judge them for their failings will struggle to convince me that

8 Thus my 'Mr Y' represents a 'best available account' in the sense of Charles Taylor (1992:58f). He conforms to what we know of Israelite farming and the attitudes to nature of later rural communities (see Thomas 1984:51-91). 
manifest lack of concern for what we partly know, human nature, betokens greater concern for what we hardly know.

Is there a disinterested concern for the environment beyond the faces of interest and concern displayed by Ms X and Mr Y? Can we rephrase Kant thus: "Always treat nature in yourself and in all things as an end and never only as a means"? ${ }^{9}$ Note that anthropocentrism came under fire when human survival came under threat and from those in a position to see this. ${ }^{10}$ I decidedly do not discount disinterested concern or claim that all interests are simply self-interest variously cloaked. I merely point out that the journey beyond perfectly natural self-interest and concern for ourselves and our species is a long one. To approach nature without the compasses by which we instinctively steer, hierarchy, self-preservation, and the like, we have to become not more but less like any part of nature we know. (Nature is ineradicably hierarchical.) In such uncharted territory, we can at most discern pointers towards the unknown - and these none too clearly.

\section{Humanity in its Environment in the Creation Stories}

The geography of Palestine is a sub-discipline of Old Testament studies not noted for novelties. Although new insights on the human geography keep pouring in, old works on the physical geography remain standard. Many consider the subject rather boring. Yet one of the boring old standard works caught my imagination years ago. Denis Baly uses the geographical data and his own experience of living in Israel to describe the tenuous life of the Palestinian peasant, who "could never experience a sense of stability in his daily life" (1967:77). The vital rainfall was unpredictable, hail, frost and snow could spell disaster and destructive swarms of locusts could eat everything green. Fierce heat, bitter cold and the enervating sirocco from the desert all plagued humans and beasts. Since major predators were still common, it was not unusual for people to be killed by wild animals, yet precious domestic animals must have been the usual victims. Grazing and browsing animals posed a threat to crops and vineyards.

Farming was hard work nearly everywhere, for Palestine is not a land of loamy plains. In the regions with a higher rainfall, agricultural land had to be protected against the invasion of natural vegetation: an untended vineyard soon became a thicket of briars and thorns. In marginal farming areas, a bad year could make sowing impossible and expose pastures to overgrazing. Thus the farmer was caught between the twin threats of the the dense thickets that could engulf arable land, and the מדבר, the semi-desert shrub land. Indeed, some parts of the land were שממה, 'desolation' - from a verbal root that also means 'to be appalled'. To such areas of rocky desert occasional thunderstorms brought further erosion rather than new life. ${ }^{11}$

If the environment presented farmers with problems, it also held out many promises. Fertile pockets of well-watered land, even odd valleys in the dry south watered by permanent streams, could be turned into 'gardens of delight'. When all went well, the earth 'produced its abundance' and the land 'gushed with milk and honey'. Birds, antelope, even

$9 \quad$ I prefer this formulation to those that speak of 'intrinsic worth' (worth outside of any relationship?). Good (explicitly hierarchical) suggestions in this regard are those of Nussbaum (1997) and Boersema (1997:234f).

10 When Kenneth Burke (1955:150) predicted long ago that ecology would become a crucial science, he was far sighted. Yet he thought of ecological concern primarily as a survival strategy (1955:v) and secondarily as a means to rally human society globally around a programme of peace. Nature 'in itself' hardly features in his works.

11 For this description, see Baly 1967:41-108. Recent accounts (Hillel 2006:140-162; MacDonald 2008:50-56) add nothing substantial and are less lively. 
the dreaded locusts, provided additional food. After the rains, streams would flow and the desert would flower. Descriptions of the good life in the Old Testament virtually always include references to agricultural abundance. The Song of Songs illustrates how closely all good things were connected to the teeming life of nature. The beauty of nature was also appreciated. $^{12}$

This was the constant tension the Israelite farmers experienced in dealings with their environment. It was manifestly 'the good land' that Yahweh had bestowed on them and equally clearly a harsh testing ground of their diligence and faith. Diligence was needed to wrest a living from an environment that was not entirely accommodating, yet diligence alone could not ensure success. Though in one sense they necessarily had to master parts of nature to live at all, they knew that they never held the upper hand - the land remained Yahweh's land. Unless modern scholars see this, they may misunderstand references to mastery of the earth and overlooks the limitations to this mastery of which Israelites could not but be aware. They may fail to notice that the promise that they will tread on lions and serpents (Ps 91:13) ${ }^{13}$ is addressed to worshippers justifiably scared of the menaces they may encounter on their journey home.

This dialectic informs the creation stories, both separately and in their tense canonical unity. When the $\mathrm{P}$ account pictures creation as a process of hierarchical ordering (Tucker 1997:7), evolutionary science does not disagree in principle (cf. Murphy \& Ellis 1996). Disagreement concerns the divine commission to humans, a theological rather than a scientific matter. But the special position of humans in creation is not the P author's first point. Humans are first of all part of creation, Yahweh's creatures along with all else. Secondarily humans are brought into a closer relationship with Yahweh than the other creatures. ${ }^{14}$ Although it is not stated, the context (extra-biblical creation stories, kingship ideology and the theology of P) suggests that the special relationship implies special responsibilities (cf. Tucker 1997:6f), particularly if 'image' means 'representative'. ${ }^{15}$ Again, it is hard to see from what theological perspective this can be challenged. Even if God can, in some way obscure to us, call other creatures to account, humans assuredly cannot. Moreover, from any perspective available to Israelites, human life (as opposed only to human death) involved a type of mastery over nature. And, since P has to be read as a whole, the $\mathrm{P}$ author was perfectly aware that this fragile mastery was no proof against the forces of nature should Yahweh call humans to account (the flood).

If the $\mathrm{P}$ account, a product of learned reflection, displays a certain 'scientific objectivity', the $\mathrm{J}$ account is 'anthropocentric' in its consistent focus on humanity. Humanity is located in a setting at once natural and protected. A $\gamma_{\lambda}$, an enclosed garden, neither a human artefact (cf. Brown 1999:138) nor 'wild nature' is the 'natural setting' for human life - as it was for the Israelite farmer (pace Newsome 2000:64). Human life requires a relationship with a natural environment from which certain aspects of nature are excluded. Adam's naming of the animals implies domination, as scholars point out, but it is also perfectly realistic. Humans survive by naming/knowing their environment, not by instinct. Here too the 'special position' accorded to humans remains in accordance with

12 Whybray (2002:6) omits the aesthetic from his list of constituents of the good life in the Old Testament, thereby creating the impression that Israel's view of nature was purely instrumental.

13 The verse is normally interpreted in the light of Gen 1 and royal iconography. But both Mays (1994:297) and Goldingay (2008:39f, 47) point out that the literal and figurative are interwoven in this psalm. As often biblical poetry, one does not have to choose one to the exclusion of the other.

14 That humans are closer to animals than to God remained standard Christian theology (Thomas 1984:124).

15 For this view, see Wolff 1974:160f; Levenson 1994:114ff. 
human knowledge. Nor does the J author draw exaggerated conclusions from this. 'Adam' (אrom (אדמה) is from one perspective but dust of the earth - as earthy as can be. Humanity is more than this only from the perspective of the conversation with Yahweh - and this conversation entails Yahweh's command and judgement. Arguably P emphasizes blessing and promise precisely because $\mathrm{J}$ had adequately addressed command and judgement.

Even in the garden of abundance, 'nature' posed a threat to human life, a realistic one, for fences do not fend off snakes. Though scholars often explore the link between snakes and fertility, the Old Testament generally portrays snakes as simply dangerous; Gen 3:15, read with Ps 91:13, suggests that this is the case here as well. There is thus a fine balance between potential and promised mastery and actual vulnerability. Outside Eden life was harder still, for there the earth produced thorns and thistles alongside fruit trees. ${ }^{16}$ Humans had to construct their own 'walls': clothes against the cold, city walls against enemies, fences around their vineyards. Survival depended on the ability to subdue the wild forces of nature, but this ability was merely relative. Relative to what? The J author could see only one answer: "To Yahweh's rule and judgement". That human abilities could ultimately endanger human survival must have seemed incredible.

As regards the relationship of humanity and its environment, both creation stories fit entirely into what we know of the concrete life of Israelites. In many respects they still stand today (cf. Tucker 1997:17). 'Responsibility' and "the need and ability to create your own environment" still apply mainly, perhaps not solely, to humans. The dialectical tension in them is still with us. But to read these stories as if they spoke directly about ecological concerns would be folly.

\section{Variations on a Theme: Humanity and Environment in the Rest of the Old Testament}

Elsewhere in the Old Testament we find many variations on the basic dialectical theme. Though only humans are in the full sense Yahweh's conversation partners, the hymns allow all of nature to join Israel in worship. When all of creation sings Yahweh's praises, the distinction between humanity and non-human nature is momentarily obscured. One should not make too much of this, for the 'official' position was always that humans are no more than creatures. Before Yahweh, the Wholly Other, minor distinctions among the creatures fade into insignificance.

The elevated reality of the hymns evades normal standards. Here the lion's roar appears as a prayer for food (Ps 104:21); even threatening manifestations of nature testify to Yahweh's glory. This does not make the lion less of a threat or snow less daunting. Hymnic reality reaches beyond daily drudgery to enable inspiring visions. All animals require food and Yahweh's care extends to them all (Mays 1994:335), even those that prey on humans and their livestock. When the earth joins Israel in welcoming Yahweh as righteous judge (Pss 96, 98), it is hinted that non-human nature too might long for and stand in need of justice. The sheer multiplicity and complexity of creatures and their beauty speak of Yahweh's wisdom (Ps 104:24), but only to those who have, at least sometimes, experienced all this with amazed delight. Finally, in the hymns Israel expressed that sense of awe at the overwhelming aspects of nature which lured others into nature worship. In Ps 8, much maligned for its statement of human lordship, the natural world is initially seen as the theatre of Yahweh's glory: in its vastness and majesty it stands on the side of Yahweh over

16 "[T] 
against humanity, representing Yahweh better than humanity does (cf. Tucker 1997:16; Lawrie 2010:609f).

But one must not mistake "the visionary world of liturgy for a description of quoditian reality" (Levenson 1994:7). In the hymns we see from a holiday and a holy day perspective. Workaday reality is forgotten and Yahweh's כבד clothes everything in splendour. For those who 'see Yahweh' - only for them - all promises are in the present and all problems in the past; the response of praise is the sole remaining responsibility. One is forced beyond materiality for the sake of material creation.

Nature plays a different role in the laments. The basic threat, refracted through many lenses, is isolation or 'social death' (Janowski 2003:47). When death, sickness, calumny, persecution or sin robs one of one's place in the civil and sacral community, one ceases to live as a human being. Since this is the central theme, animal images are invoked mainly in a negative sense: animals threaten the worshipper or the worshipper is reduced to an animal existence $(2003: 117 \mathrm{ff})$. When the imagery is not negative, it is either neutral or formal or the image is applied to Yahweh. Nature by itself cannot alleviate the worshipper's distress. Whereas the hymn tends to view all of creation panoptically in the praise of Yahweh, the lament tends to emphasize differentiation (even between humans) because the human creature's identity is threatened.

Although Is 11:6-11 promises the institutionalization of the hymnic moment, the majority of references to the environment (purely figurative ones excluded) in the prophetic books appear to be variations on the themes of the creation stories. Promises often allude to agricultural abundance and threats to natural disasters. It is unnecessary to cite examples. Images drawn from nature often strike home because they fit perfectly with the audience's lived experience. As the נחל איתן, the permanent stream, is worth any number of wadis that are torrents only when water is plentiful anyway, so justice is worth more than countless sacrifices and hymns (Amos 5:24). To a farmer who had experience of establishing a new vineyard, Is 5:1-7, fraught with judgement as it is, spoke of the reluctance of Yahweh to abandoned Judah. Again, the examples are many.

In the prophetic literature the fear of being swamped by 'wild nature' is in clear view. Oracles of doom foretell that Yahweh's wrath will turn ordered human habitations into a wilderness, that fields will lie abandoned and the ruins of cities harbour only wild animals. To become like Sodom and Gomorrah is not only to be destroyed, but to become an appalling desolation, שממה permanently unfit for human life. In this regard, the prophets testify to Israel's sense of human fragility in the face of nature. What had been established over generations can be destroyed at a stroke. The cause is Yahweh's judgement; the result is the victory of nature over human efforts.

Yahweh's punishment may involve a derailment of natural expectations: nature fails to take its normal course. The futility curses were not invented by the prophets nor were they specifically Israelite. In covenant documents they served as threats to keep the covenanting parties in line (cf. Deut 28:15-35). Essentially the threat is that people's efforts will be bootless: success will continue to elude them. Sometimes this involves a 'malfunctioning of nature': food will not satisfy hunger, wine will not make drunk, sowing will yield no harvest, copulation will not lead to pregnancy and pregnancy not to birth. In other cases the futility of the actions may have various causes: one could plant a vineyard and for various reasons not enjoy its wine. ${ }^{17}$ The emphasis is thus on the inability to attain a goal rather

17 Smoak (2008:35), who emphasizes the effect of warfare, notes that the vagueness of these two threats allowed them to be used in different concrete circumstances. That is why they occur most frequently. 
than on the 'revolt of nature' as such. Nevertheless, these curses indicate that the Israelites did not feel they could take nature for granted; natural processes were not entirely at their disposal.

Perhaps Gerhard von Rad overemphasized salvation and history at the expense of creation, but in Wisdom in Israel he partly made amends (cf. Dell 2007:61f). In it he grants that the wisdom tradition is not extraneous to Yahwism and that it deals mainly with the natural order. The order, though not independent of Yahweh and not impermeable to Yahweh's intervention (1972:100f, 105f), is relatively stable (85) and a source of inspiring wisdom (not divine inspiration; cf. 175). Von Rad speaks repeatedly of the voice of nature to which Israel had to pay heed (see 144ff). The sages did not encounter the natural order as an object to be manipulated, but as a 'thou' that addressed them (156ff). Moreover, nature discloses not only the glory of Yahweh, but itself (163f). In recognizing "a relative determinism inherent in events", the sages also recognized "a [merely] relative value in worldly things (life, property, honours, etc.)" (59). Yet wisdom, even in its apparently purely empirical form, is not divorced from the relationship with Yahweh (62ff). "Man is always wholly in the world, and he must always deal only with Yahweh" (95). While wisdom is about 'mastering life' (74) and 'coping with reality' (113), there is also an element, 'verging on the mystical', of surrender to 'the glory of existence' (169).

Von Rad does not deny that Israelite wisdom is anthropocentric, only that Israelite sages felt able to be anthropocentric without an openness - going beyond the instrumental - to creation. Still, one has to admit that Proverbs is not a spontaneous response to creation's call; it is the product of reflection and literary shaping. The sages seem more distant from the environment of the Israelite farmer than the prophets were. Their nature imagery is less extensive and striking, more fragmentary and formal. For instance, their animals are, with few exceptions, one-dimensional and static, merely representative of a single quality. ${ }^{18}$ The 'created order', apart from its thoroughly human aspects, is viewed from afar - as it might have appeared to courtiers. ${ }^{19}$

Qoheleth stands apart from the rest of the Old Testament, also in his view of the human environment. His term 'under the sun' can fairly be translated as 'nature as this earth'. It is God's creation, but is distant from the Creator, who determined its course and then apparently left it at that. ${ }^{20}$ Qoheleth misses being a deist by a hair's breadth. Because God does not intervene, there is nothing new 'under the sun': Qoheleth's 'creation story' tells of a boringly repetitive set of cycles (1:3-11). Human uncertainty stems only from our inability to comprehend God's work-plan. 'Under the sun' definitely includes humanity as a distinct but not a distinctive part. The cycles of human life resemble the cycles of nature and in death humans are...dead animals (Dell 2009:188). Whybray (1989:28f) pointed out that Qoheleth takes up and exaggerates features typical of the Old Testament. Whereas in P humans stand with the rest of creation, separate from Yahweh, before they acquire a special position, in Qoheleth God's transcendence is absolute and humanity has no significant special position. Humans, being 'radically continuous with nature', are at the

18 Ironically, the examples cited by Hobgood-Oster (2001:43f) illustrate my point: the animals are anthropomorphic puppets used for didactic purposes.

19 This does not hold for the book of Job. The wealth of its references to the natural world places it outside the scope of this article. Note, however, that it is -also in this respect - open to divergent interpretations. Thus Habel's view on the divine speeches (2001) is hardly compatible with the strongly exceptionalist one of Tsevat (1980).

20 Whereas Seow (1997:104f) takes 'under the sun' to mean 'in the realm of the living' as opposed to the netherworld, Janzen (2008:470ff) argues that the reference is to the sun's 'delegated rule'. Humans are 'under the sun' rather than 'before Yahweh' (482f). 
mercy of fate (מקרה). This is the only name under which we, being what we are, can know God's will.

Unlike the worshippers in the laments, Qoheleth does not scream for God's attention but allows God perfect freedom. Some see here acceptance of our kinship with the rest of nature, ${ }^{21}$ though this may be so, I fail to find any concern for animals or any other part of nature. The enjoyment to which Qoheleth calls us is precisely expressed in carpe diem living for today. ${ }^{22}$ This, I submit, is the logical conclusion to be drawn from the premise of radical continuity with nature. In most animals future regard is limited to the instinctive; lacking corresponding instincts, humans can entertain only prudential elements of future regard. In fact, there are hints that Qoheleth views even dealings among humans as purely instrumental $(4: 4,9-12)$. There is no hope for the earth in this. Qoheleth the witty academic has "sicklied o'er with the pale cast of thought" all that is vital in humanity and nature. Though Qoheleth's author is not necessarily mirrored in his text (cf. Fox 1999:372f), the text as such presents an inverted mirror image of the hymns. In the latter humanity and the rest of nature are joyfully joined in God's presence; in the former humanity and nature share the futility brought about by God's absence.

\section{Materialism and its Beyond}

No part of the Old Testament can speak directly to the current ecological crisis; I cannot but do so - aware that my view is no less limited, albeit in different ways. How can the Bible broaden my horizon? Rejoicing in 'green texts' and deploring 'grey texts' does not rid us of the tendency to deal with all things instrumentally - as means to our current goals. ${ }^{23}$ Recasting our thought along 'biocentric' rather than 'anthropocentric' lines will not help either. Abstractions at the far edges of consciousness abstract too much from the material base of anthropocentrism that Burke (1966:90) called 'the centrality of the nervous system'. Moreover, this fight against the notion of human mastery reinstates the same notion in a more patently false way by suggesting that we can create and recreate worlds, people included, by mental gymnastics.

In the Old Testament terms such as 'the environment as promise and problem', human mastery, human frailty and human responsibility are delineated (given shape and limits) from within a context. Being informed (shaped from the inside) by a mode of life, each notion had its scope and boundaries: it was as realistic to speak of mastery as it was to recognize it limits. Israelites did not have a single, coherent world-view (Von Rad 1972:308; Brown 1999:5), but overlapping, intersecting, competing views that responded to the concrete facts of their lives. The earth could be a loving mother nurturing her children or a cruel ogre strangling them at birth. It is to Israel's credit that in her best moments she worshipped neither the mother nor the ogre. To think we have a single answer where they needed many is not merely arrogant; it is unrealistic.

21 Neither Dell (2009), who emphasizes the kinship between humans and the rest of nature in Qohelet, or Van Heerden (2001:163f), who emphasizes that Qoheleth rejects hierachies, adequately considers that this devalues humans without adding any value to non-human nature.

22 Not that I regard Qoheleth as a 'preacher of joy' as, for instance, Gordis (1978), Whybray (1982) and Lee (2005) do. For my arguments, see Lawrie 1997:269ff; 2010:614ff.

23 Habel (2009:xvii) denies that 'being green' is 'a backhanded way of protecting humans', yet if empathy for 'Earth' excludes empathy for humans, 'Earth' is curiously conceived. In pushing his awareness against that of others, Habel is necessarily - but by no means reprehensibly - 'grey'. The issue is ethical and, as Midgley (1994:138) points out, ethics deals with clashing motives, not with oneness. 
We need a realistic assessment of the limited mastery we have if we are to avert, even partially, the disaster we are creating. Without the instrumentation of human mastery reason and the technology it creates - we cannot undo what we have done. Animal instinct and identification with the planet won't do. We need a realistic sense of our fragility and that of the planet if we are to direct our instrumentation to the right purposes in time. We need to see that the promises and problems of the environment have become problems for the environment, with little promise for us or the environment, unless we shoulder responsibility. Since we are apparently the only creatures on earth that respond to moral imperatives, ${ }^{24}$ we cannot shift responsibility to creatures in which future regard is limited to the instinctual. "Nature cannot become a norm, but the quality of our norms can be derived from our dealings with nature" (Boersema 1997:253).

With responsibility and the ethical we have already moved beyond the purely material, ${ }^{25}$ or, if Murphy and Ellis (1996:57) are right, towards the transcendence that is implicit in the material world. But, not towards new ideas. The imperative that goes beyond mastery and the instrumental, "to treat as an end and not merely as a means", requires us to do certain things, not to think in certain ways. ${ }^{26}$ When it comes to doing, those who endorse Kant's principle of humanity - as many non-Kantians do - do not fare significantly better than those who have never heard of Kant. Christians, in spite of their doctrine of love, have been greedy, warlike and imperialistic. The Chinese, for all their emphasis on cosmic harmony, were well ahead of the West in degrading the environment before the tables were turned. ${ }^{27}$ Traditional societies saw God in nature, hunted species to extinction and burned forests to provide grazing land. ${ }^{28}$ Humans, as Flannery (2001:192) says, had "an unequalled potential for destruction" practically from the start - not from the moment they started thinking in a particular way.

Strictly speaking, only God is capable of disinterested concern for all of creation. We approach this (at a distance) in as much as we approximate a God's eye view and God's empathy that does not depend on reciprocity. The signpost to ecological ethics points to God before it points to nature. From the latter, read first and in isolation, we hear only of instinctual determinism, survival and instrumental relationships; the Old and especially the New Testament sometimes take us further. The vision of the hymns - a gift, not a capability - has us standing alongside the rest of nature facing Yahweh in praise. From 'seeing Yahweh' we may turn to view creation with new eyes. Thus 'knowledge of Yahweh' (יהוה) דעת in the Old Testament sense) humanizes and naturalizes us at the same time.

It also - I say this with hesitation - divinizes us, though only in a quite specific sense. In responding to God, we become able, albeit to a tiny extent, to mediate God's boundless

24 Midgley (1994:138f) points out that we cannot know much about the 'ethics' of other animals, but then gives a cogent (hierarchical!) account of the possible similarities and differences (170ff).

25 Not necessarily beyond Marx. The tension between the ethical and the scientific strains in Marxism has often been noted and is dealt with in detail by Gouldner (1980).

26 To say "What people do about their ecology depends on what they think about themselves in relation to things around them" (White, quoted with approval in Tucker 1997:4) is perilously one-sided, as is the opposite. Much can be done within fairly traditional frames of thought using the modest suggestions of Kenoti (2006) not pulped trees.

27 By the late $11^{\text {th }}$ century, northern China produced more iron than Britain did seven centuries later (Kennedy 1989:5). On early Chinese industry and its decline, see Elvin 1973:84ff, 285ff; Kennedy 1989:5ff, 191. The environmental impact can be judged from the fact that northern China was already completely deforested by the $11^{\text {th }}$ century to supply charcoal (Elvin 1973:85); much of it is now desert.

28 On the environmental impact of hunter-gatherers, particularly through excessive hunting and use of fire, see Ponting 1991:33ff; Ames \& Maschner 1999:46, 120, 253; Flannery 2001:186-205; 221-229. 
love for all of creation. I call this response creative kenosis. It is Godlike in being both creative and kenotic. To empty ourselves and serve the world we need whatever fullness and strength we can muster - empty, weak servants render no service. The strong kenosis of Jesus (not the ideas of Jesus) brought forth a new creation; weak kenosis identifies itself with the decay of creation. There is a paradox here: we need to become very weak to be strong at all and very high to reach down low enough to be of use. But other paradoxes are far worse. We may end up being at once insufficiently theological and insufficiently materialistic, caught in both insubstantial idealism and uncritical worship of nature. ${ }^{29}$

I leave the last word to HH Schmid (quoted in Steck 1978:290): “'Gospel' would then be the synonym neither for 'changing the world' nor for 'unworldliness'; it would mean laying the foundation for a possible world and a possible human existence under the ultimate definition of salvation: taking the world seriously, but just because of that not overvaluing it; closely related to it but, just because of that, making a fundamental distinction between God and the world; seeing the world as God's creation but, just because of that, preserving the eschatological proviso."

\section{BIBLIOGRAPHY}

Ames, Kenneth M \& Maschner, Herbert DG 1999. Peoples of the Northwest Coast. London: Thames \& Hudon.

Avineri, Shlomo 1971. The Social and Political Thought of Karl Marx. Cambridge: Cambridge University Press.

Baly, A Denis 1967. The Geography of the Bible. London: Lutterworth.

Boersema, Jan J 1997. Thora en Stoa. Baarn: Callenbach.

Brown, William P 1999. The Ethos of the Cosmos. Grand Rapids: Eerdmans.

Burke Kenneth D 1955. Attitudes Toward History ( $2^{\text {nd }}$ ed.). Berkeley/Los Angeles: University of California Press

Burke, Kenneth D 1966. Language as Symbolic Action. Berkeley/Los Angeles: University of California Press

Dell, Katherine J 2007. “God, Creation and the Contribution of Wisdom." In RP Gordon (ed.), The God of Israel, 60-72. Cambridge: Cambridge University Press.

Dell, Katharine J 2009. "The Cycles of Life in Ecclesiastes." Vetus Testamentum 59, 181-189.

Elvin, Mark 1973. The Pattern of the Chinese Past. Stanford: Stanford University Press.

Flannery, Tim 2001. The Eternal Frontier: An Ecological History of North America and Its Peoples. London: Heinemann.

Fox, Michael V 1999. A Time to Tear Down and a Time to Build Up. Grand Rapids: Eerdmans.

Goldingay, John 2008. Psalms Volume 3. Grand Rapids: Baker.

Gordis, Robert 1978. Koheleth: The Man and His World ( $3^{\text {rd }}$ edition). New York: Schocken.

Gouldner, Alvin W 1980. The Two Marxisms. London: MacMillan.

${ }^{29}$ Coleridge spoke of Wordsworth's worship of nature as 'misty' not 'mystical' (quoted in Thomas 1984:302). 
Hillel, Daniel 2006. The Natural History of the Bible. New York: Columbia University Press.

Habel, Norman 2001. "Earth First: Inverse Cosmology in Job." In NC Habel \& S Wurst (eds.), The Earth Story in Wisdom Traditions, 65-77. Sheffield: Sheffield Academic Press.

Habel, Norman 2009. An Inconvenient Text. Adelaide: ATF Press.

Hobgood-Oster, Laura 2001. "Wisdom Literature and Ecofeminism.” In NC Habel \& S Wurst (eds.), The Earth Story in Wisdom Traditions, 35-47. Sheffield: Sheffield Academic Press.

Jacobs, Louis 1995. The Jewish Religion. Oxford: Oxford University Press.

Janowski, Bernd 2003. Konfliktgespräche mitt Gott: Eine Anthropologie der Psalmen. Neukirchen-Vluyn: Neukirchener Verlag.

Janzen, J Gerald 2008. “"Qohelet on Life 'Under the Sun'.” $C B Q 70,465-483$.

Kennedy, Paul 1989. The Rise and Fall of the Great Powers. London: Fontana.

Kinoti, George 2006. "Christians and the Environment." In T Adeyamo (ed.), Africa Bible Commentary, 616. Nairobi: WordAlive.

Lawrie, Douglas 1997. "Wat beteken dit om Kohelet ernstig op te neem?” NGTT 38, 268-283.

Lawrie, Douglas 2010. "The Dialectic of Human Dignity and Human Finitude in the Psalms and the Wisdom Literature." Scriptura 105, 608-620.

Lee, Eunny P 2005. The Vitality of Enjoyment in Qohelet's Theological Rhetoric (BZAW 353). Berlin: De Gruyter.

Levenson, Jon D 1994. Creation and the Persistence of Evil (2nd edition). Princeton: Princeton University Press.

MacDonald, Nathan 2008. What Did the Ancient Israelites Eat? Grand Rapids: Eerdmans.

Marx, Karl \& Engels, Friederich 1948 (1848). Manifesto of the Communist Party. New York: International Publishers.

Marx, Karl ${ }^{30} 1970$ (1932). The German Ideology (Abridged edition, edited by CJ Arthur). New York: International Publishers.

Marx, Karl 1973 (1939). Foundations of the Critique of Political Economy ("Grundrisse", translated by M Nicolaus). Harmondsworth: Penguin.

Marx, Karl 1978a (1888). “These on Feuerbach.” In RC Tucker (ed.), The Marx-Engels Reader, 143-145. New York: Norton.

Marx, Karl 1978b (1852). "The Eighteenth Brumaire of Louis Napoleon.” In RC Tucker (ed.), The Marx-Engels Reader, 594-617. New York: Norton.

Mays, James L 1994. Psalms (Interpretation). Louisville: Westminster John Knox.

Midgley, Mary 1994. The Ethical Primate. New York: Routledge.

Murphy, Nancy \& Ellis, George FR 1996. On the Moral Nature of the Universe. Minneapolis: Fortress.

Newsome, Carol 2000. "Common Ground: An Ecological Reading of Genesis 2-3." In NC Habel \& S Wurst (eds.), The Earth Story in Genesis, 60-72. Sheffield: Sheffield Academic Press.

30 The work as a whole was written by Marx and Engels but Section I, from which I quote, is attributed to Marx. 
Nussbaum, Martha C 1997. Facing Animal Complexity. Unpublished article available at: www.hcs.edu/ hrp/facing_animals-nussbaum.pdf (accessed 6 June 2011).

Ponting, Clive 1991. A Green History of the World. New York: Penguin.

Rad, Gerhard von 1972. Wisdom in Israel (translated by JD Martin). London: SCM.

Seow, Choon-Leong 1997. Ecclesiastes (AB 18C). New York: Doubleday.

Smoak, Jeremy D 2008. "Building Houses and Planting Vineyards: The Early InnerBiblical Discourse on an Ancient Israelite Wartime Curse." JBL 127/1, 19-35.

Steck, Odil Hannes 1978. World and Environment. Nashville: Abingdon.

Taylor, Charles 1992. Sources of the Self. Cambridge: Cambridge University Press.

Thomas, Keith 1984. Man and the Natural World. London: Penguin.

Tsevat, Matitiahu 1980. "The Meaning of the Book of Job" In The Meaning of the Book of Job and Other Biblical Studies, 1-37. New York: Ktav.

Tucker, Gene M 1997. "Rain on a Land Where No One Lives: The Hebrew Bible on the Environment." JBL 116/1, 3-17.

Van Heerden, Willie 2001. "Ecclesiastes 3:16-22: An Ecojustice Reading with Parallels from African Wisdom." In NC Habel \& S Wurst (eds.), The Earth Story in Wisdom Traditions, 155-167. Sheffield: Sheffield Academic Press.

Watson, Rebecca S 2005. Chaos Uncreated (BZAW 341). Berlin: De Gruyter.

Whybray, R Norman 1982. "Qoheleth, Preacher of Joy.” JSOT 23, 87-98.

Whybray, R Norman 1989. Ecclesiastes (NCBC). Grand Rapids/London: Eerdmans/Marshall, Morgan \& Scott.

Whybray, R Norman 2002. The Good Life in the Old Testament. London: T \& T Clark.

Wolff, Hans Walter 1974. Anthropology of the Old Testament (translated by M Kohl). London: SCM. 